\title{
Hurricane Debris and Damage Assessment for Florida Urban Forests
}

\author{
Francisco J. Escobedo, Christopher J. Luley, Jerry Bond, \\ Christina Staudhammer, and Charles Bartel
}

\begin{abstract}
A random 10\% sample of communities in highly-impacted counties from the 2004 and 2005 Florida, U.S. hurricane seasons were used to study tree debris generation and damage from seven hurricanes. Woody debris amounts in cubic meters $\left(\mathrm{m}^{3}\right)$ (cubic yards; $\mathrm{yd}^{3}$ ) as well as rates and costs for cleanup, tree removal and pruning were obtained for these events. Average debris generation per $30.5 \mathrm{~m}(100 \mathrm{ft})$ of street segment ranged from $0.59 \mathrm{~m}^{3}\left(0.77 \mathrm{yd}^{3}\right)$ for low damage, $3.4 \mathrm{~m}^{3}\left(4.44 \mathrm{yd}^{3}\right)$ for moderate damage, and $17.47 \mathrm{~m}^{3}\left(22.85 \mathrm{yd}^{3}\right)$ for high damage levels; cost of removal and disposal averaged $\$ 28.25 \mathrm{per}^{3}\left(\$ 21.47\right.$ per yd $\left.\mathrm{yd}^{3}\right)$. Most communities used unit costing to account for tree removal and pruning rates, averaging $2 \%$ and $28 \%$ of street trees, respectively. Tree canopy, wind speed, and percentage of urban developed land all had a significant effect on debris amount. Florida communities with a greater tree density generated decreased amounts of debris during the 2004 and 2005 hurricane season. These results can be used to help communities plan for hurricane management activities and estimate potential damages to their tree resource.

Key Words. Emergency Management; Hurricane; i-Tree; Tree Pruning; Tree Removal; Urban Forest Management; Wind Damage.
\end{abstract}

Studies in Florida (U.S.) and elsewhere have documented the impact of hurricane force winds on urban forest structure, damage to woody vegetation, harm to forested landscapes, and of the varying resistance of different tree species (Duryea 1997; Duryea et al. 2007a; Duryea et al. 2007b; Everham and Brokaw 1996; Francis and Gillespie 1993; Gresham et al. 1991; Mayer et al. 2007; Oswalt and Oswalt 2008). Studies have also demonstrated that hurricane winds and storm surges can severely damage individual trees and landscapes, causing trees to defoliate, partially break, drop branches, topple, or uproot (Duryea et al. 2007a; Francis and Gillespie 1993; Gresham et al. 1991). Hurricanes can also alter the structure and function of ecosystems (Kupfer et al. 2008; Oswalt and Oswalt 2008). To effectively plan and manage hurricane-prone urban forests in Florida, the effects of wind storms must be taken into consideration (Escobedo et al. 2007).

The aftermath of a hurricane often includes a large amount of debris from infrastructure or landscape damage, which may result in the need to prune or remove hurricane-damaged trees (FEMA, 2007a). The cost of cleaning up debris and the remediation of tree damage is borne by local communities, but may be offset if a declaration of a federal disaster is made by the President of the United States, which hedges costs through reimbursement programs as designated by the Stafford Act (FEMA, 2007b). The ability to quantify tree debris to be removed and other tree-related costs quickly and accurately after a storm impacts the reimbursement monies requested by the Federal Emergency Management Agency (FEMA) and, indirectly, the communities' relations with FEMA during the recovery operation. Methods that estimate tree-related debris and damage from ice storms have been used to develop protocols and tools to assist communities with post-storm recovery activities (Bloniarz et al. 2001).

Non-sediment hurricane debris is generally categorized, and in certain cases reimbursed, in two broad categories: clean wood, and construction and demolition (FEMA, 2007a). Although models from the United States Army Corps of Engineers
(USACE) estimate that hurricane-generated debris consists of $30 \%$ clean woody debris, state emergency services reported that up to $70 \%$ of the debris removed after Hurricane Floyd in North Carolina was composed of vegetation (COES, 2005). Following Hurricane Ivan in September 2004, Escambia County, Florida reported that almost $90 \%$ of all hurricane debris removed was composed of vegetation (Escambia County, 2004).

Debris removal and disposal is an enormous problem for storm-affected communities. For example in 1992, 11.5 million cubic meters (15 million cubic yards) were reported following Hurricane Andrew (Ward 2002). A report from mid-2006 stated that more than $\$ 1$ billion had been spent in the state of Florida for Hurricane Wilma recovery efforts alone, and that $\$ 2.3$ billion had been sent to Florida up to that point for the 2004 storm season (FEMA, 2006a). Typically, about half of such recovery costs were likely due to debris management (Ward 2002).

There are few methods in existence for accurately estimating urban forest debris following hurricanes. Currently, the USACE debris estimation model produces a debris estimate for an affected area based on the number of households and categories for heavy, medium, and low amounts of vegetation (FEMA, 2007a). This model is acknowledged to have an error of nearly $30 \%$. Elsewhere, Broward County, Florida developed a Geographical Information Systems (GIS) based Hurricane Debris Estimation Tool that accounts for tree and palm debris (Umpiere and Margoles 2005). The tool uses tree and palm cover and assumes a tree to palm ratio and debris volume per affected tree, per unit area.

The FEMA HAZUS hurricane module uses tree density and tree height data to derive tree-loss curves for estimating downed tree debris following hurricanes (FEMA, 2006b). However, the tree-loss curves only consider trees greater than 9.14 $\mathrm{m}(30 \mathrm{ft})$ in height. Validation using actual tree debris estimates showed that this model over-estimated tree debris by approximately $90 \%$ in Virginia and $41 \%$ in North Carolina states (FEMA, 2006b). A standardized method for estimating ice 
storm damage and debris costs is available as the Storm Damage Assessment Protocol, a component of the i-Tree program (www.iTreeTools.org). However, this protocol does not specifically account for hurricane damage profile and management.

Urban forests in Florida encompass a wide variety of species, urban morphologies, and land cover types. Any protocol that is developed must be applicable over this range of variability. Most studies on hurricane effects on urban and natural forest are based on single tree, plot or landscape-scale based assessments (Duryea et al. 2007a, Duryea et al. 2007b; Francis and Gillespie 1991; Kupfer et al. 2008; Oswalt and Oswalt 2008). Many debris assessments use empirical studies such as these as inputs for broad-based, often single-parameter models and approaches for quantifying debris (FEMA, 2007a).

This study takes a different approach, and uses on-ground data reported from hurricane impacted communities to assess and characterize debris and damage at the urban and community forest level. Its objectives are to assess, compile, and analyze urban forest debris and tree damage data from the 2004 and 2005 hurricane seasons in Florida. These estimates can then be used to develop a hurricane debris assessment protocol that estimates potential damage before a storm and report tree debris and damage after a hurricane in Florida.

\section{MATERIALS AND METHODS}

\section{Debris and Tree Damage Data Collection}

We examined recent hurricanes making landfall in Florida: Charley, Francis, Ivan, and Jeanne in 2004; and Dennis, Katrina, and Wilma in 2005. An initial sample of hurricane-affected coastal and inland communities was used to determine the utility of FEMA Project Worksheets (PWs) for quantifying tree debris, damage, and costs.

Project Worksheets are compiled by each community requesting public, monetary assistance for hurricane damage, and constitute a dynamic record of information and data needed for justification for reimbursement in an emergency management project (FEMA, 2007c). Project Worksheets are categorized by the type of hurricane damage. We sampled Category A, the debris damage category, which contains relevant debris data as well as hazard tree pruning and removal reimbursement; and Category $\mathrm{G}$, which is a general category that often contains debris data. Project Worksheets were obtained from the Florida Division of Emergency Management. The initial sample of PWs from 15 communities from the 2004 and 2005 hurricane seasons in Florida provided enough data to justify their use in obtaining debris quantity and cleanup costs.

A list of Florida communities impacted by each of the seven hurricanes during 2004 and 2005 with PW applications in Category A was compiled and each community was then assigned a unique number. Using the unique number and a random number generator, a $10 \%$ sample of communities impacted as depicted in maps (FEMA, 2004) by each hurricane was then selected for use in this study. Entities other than communities (e.g., counties, tribes, official departments, hospitals) were excluded from the sample. Stump removal, for which insufficient data were available, was also excluded from the data collection.

Data for debris amounts and reported costs were taken directly from the PWs. Individual cost line items were not specifically listed by many communities. In addition to removal and reduction of debris, individual costs might have included debris monitoring, site preparation, tipping fees, equipment or other costs that were directly related to debris elimination. Debris quantity and costs were commonly reported in several different PWs for a hurricane by a single community. Therefore, data from all PWs for a single hurricane event were summarized along with community specific data as presented in Table 1 . Data on both tree removals and hazard prunings were less consistently reported in PWs. Data was obtained by direct request from the communities.

Table 1. Data collected for each hurricane and community.

\begin{tabular}{ll}
\hline Data & Source \\
\hline Public street miles & TIGER/Line files (US Census Bureau \\
& 2004) \\
$\%$ developed urban land & USDA Forest Service (Nowak et al. \\
\% tree cover & USDA Forest Service (Nowak et al. \\
& 2008) \\
Tree density (per hectare) & University of Florida (Escobedo et al. \\
& 2008) \\
Sustained wind speed (knots) & National Oceanic and Atmospheric \\
& Administration (NOAA, 2004) \\
Debris and costs & Project Worksheets \\
Tree removal and pruning costs & Project Worksheets, Community contact \\
Tree removal and pruning totals & Project Worksheets, Community contact \\
Total vegetation debris ( ${ }^{3} ;$ yd ${ }^{3}$ ) & Project Worksheets \\
Total cost for debris disposal & Project Worksheets \\
Community center $($ UTM) & Google Earth (Google Earth, 2007) \\
\hline UTM = Universal Transverse Mercator
\end{tabular}

Hurricane debris amounts and costs, urban forest tree density and cover data, street mileage, and percent of urban developed land were derived from a number of sources (Table 1). Maximum sustained wind speed data for each community were obtained from tabular data (NOAA, 2004), and reported for selected communities by the National Hurricane Center. Where wind speed data were not available for a sample community, wind speeds were assigned to sample communities based on nearest community with a recorded wind speed.

Debris data were converted to a total cost per cubed meter by summing all reported debris volume disposed and its associated costs from PWs. Estimates of debris generation per unit street segment length were made with i-Tree's "Sample Street Segment Generator" using ArcGIS 9.1 and street mileage obtained from U. S. Census Bureau's TIGER/Line data (U.S. Census Bureau, 2004), in an ESRI shapefile (i-Tree 2008).

Relationships between tree cover, density, and debris amounts collected from Street Rights-of-Way were investigated using Renewable Natural Resources Planning Act (RPA) assessment urban forest cover data tabulated by Census Designated Place (Nowak et al. 2008). These data are based on $30 \mathrm{~m}$ resolution Landsat TM and ETM imagery that is part of the 2001 National Land Cover Database. RPA data included percent tree canopy and developed urban land for each sampled community (Table 1). Percent canopy was converted to community-specific tree density using representative mean tree density factors from similar geographic and physiographic communities (Escobedo et al. 2008). Communities in north Florida were assigned Pensacola's tree density of 315 trees/ha (127 trees/ac), Tampa Bay's tree density of 257 trees/ha (104 trees/ac) was used for the central Florida gulf coast, MiamiDade Counties' 83 trees/ha ( 34 trees/ac) for south Florida and lower Atlantic coast, and Gainesville's 242 trees/ha (98 trees/ac) were used for communities in central Florida's non-coastal areas.

The distribution of cubic meters of debris per linear street segment data was determined to be significantly different from 
normal. To most appropriately characterize the positively skewed data, cubic yards of debris were transformed with the natural logarithm, and the number of linear street miles was used as an offset in the linear predictor function. As offsets are akin to exposure rates in Poisson regression with unequal time intervals, their use in spatial models is frequently used to adjust the response to varying levels of coverage. Using a log-normal distribution to characterize the response variable and taking into account the potential spatial correlation between adjacent cities, a generalized linear mixed model was fit with the SAS procedure PROC GLIMMIX (SAS, 2006), using sustained maximum wind speed, tree density, tree canopy, and the amount of developed urban land as predictor variables. City center location was obtained using Google Earth (2007) (UTM; Universal Transverse Mercator, Northing and Easting) and used to determine spatial context in the analysis.

The model results were examined using information criteria and $P$ values associated with each independent value. A type I error level of 0.10 was used to eliminate non-significant effects and their interactions, together with the corrected Akaike's information criteria (AICC), which is a small sample bias-corrected version of the AIC fit statistic. The AICC quantifies the residual variance, with a penalty term for additional independent variables. The final estimated model included only significant effects and also had the lowest AICC, indicating substantial evidence that the data arose from this model.

\section{RESULTS}

\section{Data Collection}

A random 10\% sample of $680 \mathrm{PWs}$, representing the communities reporting debris data in FEMA category A or G in the 2004 and 2005 hurricane seasons, were reviewed to compile and assess debris amounts and cost, as well as tree hazard pruning and removal data. From the 68 PWs, we obtained usable debris amounts and cost data from 43 communities. However, tree pruning and removal data were considerably less available, with only 11 communities specifically referencing tree work in their PWs, and only 5 communities providing usable pruning and removal cost estimates. No usable data were obtained from any PW for community for tree removal or pruning rates (removal or pruning quantities/total tree population). These data were obtained from direct contact with the communities of Orlando, Pensacola, and Winter Park. Averages for the sampled communities are presented in Table 2.

\section{Debris Removal Costs and Production}

Total debris management costs averaged $\$ 28.11$ per $\mathrm{m}^{3}(\$ 21.50$ per $\left.\mathrm{yd}^{3}\right)$ in the 43 communities that provided usable data. Debris production per $30.5 \mathrm{~m}$ street segment ranged in values from $0.15 \mathrm{~m}^{3}\left(0.2 \mathrm{yd}^{3}\right)$ in Sanford, to $31 \mathrm{~m}^{3}\left(40.6 \mathrm{yd}^{3}\right)$ and $46.4 \mathrm{~m}^{3}$ $\left(60.7 \mathrm{yd}^{3}\right)$ in Golf and Gulf Breeze respectively. Thus, rates of debris production were averaged into low, moderate, and high categories. These averages, per street segment, were 0.59 $\mathrm{m}^{3}\left(0.77 \mathrm{yd}^{3}\right)$ for low damage, $3.40 \mathrm{~m}^{3}\left(4.45 \mathrm{yd}^{3}\right)$ for moderate damage, and $17.47 \mathrm{~m}^{3}\left(22.85 \mathrm{yd}^{3}\right)$ for high damage levels.

Tree density, tree canopy cover, wind speed, and percentage of urban developed land all had an effect on the amount of cubic meters of debris. The model which included all significant effects and best supported the data based on the AICC (169) included a third order interaction of tree canopy cover, wind speed, and percentage of urban developed land $(\alpha<0.10)$ (Table 3$)$.

There was a marginally significant negative correlation between tree density and debris generation $(P=0.08)$, indicating that as tree density in communities increased there was a slight decrease in debris (Table 3, Figure 1a). Because of the significant interactions among variables, the effects of tree canopy cover, wind speed, and percentage of urban developed land were examined in conjunction with the other variables. Tree canopy cover had a positive relationship with debris when the interactions among variables were taken into account and all other predictor variables were at their averages; as canopy cover increased in a community, debris generation increased (Figure 1b). Sustained wind speed and amount of developed urban land had a more complex effect, and when considered with all other interactions their effect on debris was relatively flat (Figure 1c, Figure 1d).

Figure $2 \mathrm{a}$ and Figure $2 \mathrm{~b}$ display the continuous two-way interaction of wind speed when percent developed urban and tree canopy cover were held at constant "low" and "high" values. Debris generation strongly decreased with increasing storm strength when communities had a high tree canopy cover

Table 2. Tree cover, developed urban land cover, tree density, wind speed, and debris generation for the communities and hurricanes sampled in the 2004-2005 seasons.

\begin{tabular}{|c|c|c|c|c|c|}
\hline \multirow[b]{2}{*}{$\begin{array}{l}\text { Sampled } \\
\text { Hurricanes }\end{array}$} & \multicolumn{5}{|c|}{ Average for sampled communities } \\
\hline & $\begin{array}{l}\text { Tree } \\
\text { canopy } \\
\text { cover }(\%)\end{array}$ & $\begin{array}{l}\text { Developed } \\
\text { urban cover } \\
(\%)\end{array}$ & $\begin{array}{l}\text { Tree } \\
\text { density per } \\
\text { ha (acre) }\end{array}$ & $\begin{array}{l}\text { Sustained } \\
\text { wind speed } \\
\text { (in knots) }\end{array}$ & $\begin{array}{l}\mathrm{m}^{3}\left(\mathrm{yd}^{3}\right) \\
\text { per } 30.5 \mathrm{~m} \\
(100 \text { feet })\end{array}$ \\
\hline Charleyz $^{2}$ & 37 & 58 & $12.7(31.3)$ & 59.3 & $9.6(12.5)$ \\
\hline Frances $^{y}$ & 23 & 68 & $7.0(17.3)$ & 46.6 & $4.0(5.2)$ \\
\hline $\operatorname{Ivan}^{x}$ & 26 & 75 & $13.6(33.6)$ & 43.7 & $24.3(31.8)$ \\
\hline Jeanne $^{w}$ & 12 & 80 & $3.7(9.2)$ & 38.8 & $1.9(2.5)$ \\
\hline Dennis $^{v}$ & 26 & 77 & $13.6(33.6)$ & 56.3 & $8.0(10.4)$ \\
\hline Katrina $^{u}$ & 12 & 81 & $4.6(11.2)$ & 45.2 & $1.0(1.4)$ \\
\hline Wilma $^{t}$ & 10 & 80 & $1.4(3.4)$ & 60.9 & $13.6(17.8)$ \\
\hline Study Average & 19 & 75 & $6.7(16.6)$ & 49.1 & $7.1(9.2)$ \\
\hline
\end{tabular}

ha = hectare;

${ }^{z}$ Oviedo, De Land; Orange City; Port Orange.

y Atlantic Beach; Tampa; Palm Beach Gardens; Palm Springs; Gulf Port; Sanford; Fort Pierce; Daytona Beach; Debary; Deltona; Edgewater.

${ }^{x}$ Destin; Fort Walton Beach; Gulf Breeze.

w Oakland Park; Pompano Beach; Palmetto; Belle Isle; Belle Glade; West Palm Beach; Clearwater; Gulf Port

v Destin; Fort Walton Beach; Mary Esther; Gulf Breeze.

"Lauderhill; North Lauderdale; Pembroke Pines; Aventura; Surfside; Gulf Breeze.

${ }^{t}$ Lauderdale Lakes; Fellsmere; Opa-locka; Atlantis; Belle Glade; Greenacres; Golf. 
Table 3. Parameter estimates from the final generalized linear mixed model of cubic yards of debris, using street miles per community as an offset.

\begin{tabular}{lrrrr}
\hline Effect & Estimate & $\begin{array}{l}\text { Standard } \\
\text { error }\end{array}$ & $\mathrm{t}$ Value & $\operatorname{Pr}>|\mathrm{t}|$ \\
\hline Intercept & 10.652 & 9.299 & 1.150 & 0.260 \\
Tree density (trees/hectare; TPH) & -0.150 & 0.083 & -1.800 & 0.080 \\
Developed urban cover \% (DUC) & -68.321 & 34.953 & -1.950 & 0.059 \\
Tree canopy cover \% (TCC) & -11.857 & 11.097 & -1.070 & 0.293 \\
Sustained wind speed (knots; SWS) & -0.024 & 0.195 & -0.120 & 0.902 \\
DUC X SWS & 0.216 & 0.230 & 0.940 & 0.354 \\
TCC X SWS & 1.436 & 0.689 & 2.080 & 0.045 \\
TCCX DUC & 157.520 & 51.289 & 3.070 & 0.004 \\
TCC X DUC X SWS & -2.954 & 0.994 & -2.970 & 0.005 \\
\hline
\end{tabular}

(Figure 2a). For communities with low tree canopy cover, stronger storms produced more debris, but with a much weaker relationship. The amount of urban development also had a differential effect when considered with wind speed. The positive correlation indicated greater debris generation with increased wind speed for communities with low urban development (Figure 2b). For communities with high urban development, however, debris generation was lower with increasing winds.

Tree Removal and Hazard Pruning Costs and Rates All communities that reported tree removal and pruning data in PWs or were contacted directly, used unit costing rather than time and material for individual trees to account for these costs. Reported unit tree removal and pruning costs averaged $\$ 447$ for tree removals and $\$ 147$ for hazard tree pruning. Data from Orlando indicated that the current per-man hour rate for a fully equipped tree crew was $\$ 50$. Post-hurricane street tree removal and pruning rates were obtained using Pensacola and Winter Park data. Removal rates averaged $0.65 \%$ for Pensacola and $3.6 \%$ for Winter Park, for an average of $2 \%$. Pruning rates averaged 34\% for Pensacola and 23\% for Winter Park, for an average of $28 \%$. Winter Park data represented the average of three hurricanes that occurred sequentially in the 2004 season.

\section{DISCUSSION AND CONCLUSION}

Characterization of hurricane debris and damage is scale-dependent and can vary from the individual tree to the landscape level (Duryea et al. 2007a; Duryea et al. 2007b; Everham and Brokaw 1996; Francis and Gillespie 1991; Kupfer et al. 2008; Oswalt and Oswalt 2008). Differences in the range and variability of weather, urban forest structure, tree species characteristics, landscape morphology, and community values can also confound findings (Kupfer et al. 2008). However, this complexity might assist in understanding the recurrent contradictory or ambiguous results from this and other studies of hurricane-caused damage to treed landscapes.

The majority of communities that were sampled for this project did not measure hurricane-level winds greater than $121 \mathrm{~km} / \mathrm{h}$ (75 mph; $65.2 \mathrm{kt}$ ) based on the sustained wind speeds reported by NOAA (2004); wind speeds ranged from $48 \mathrm{~km} / \mathrm{h}$ (30 mph;

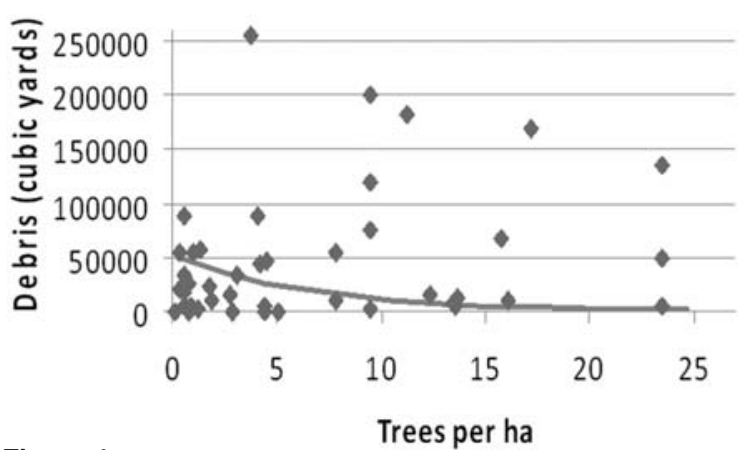

Figure 1a

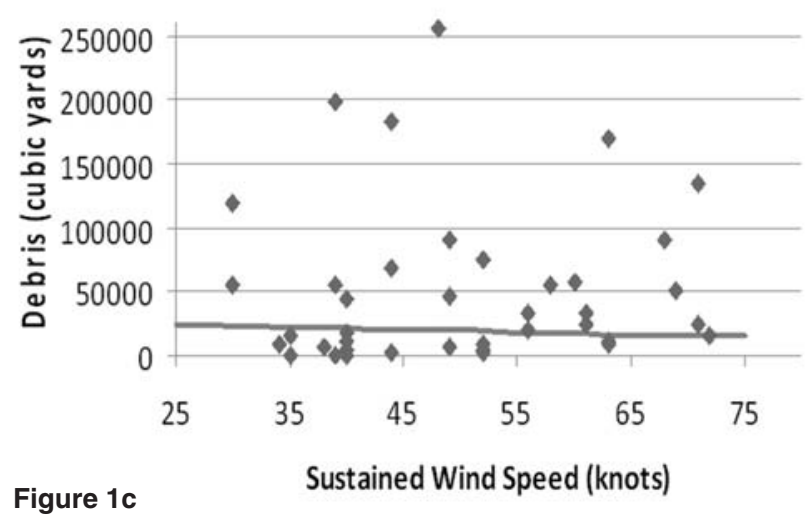

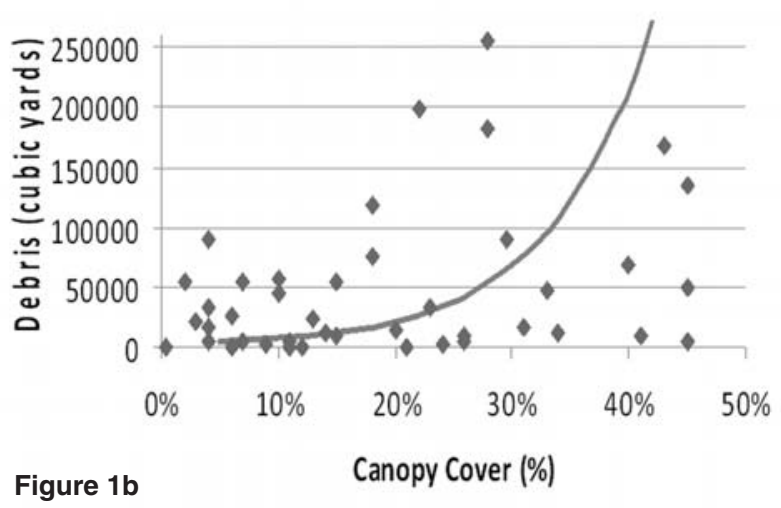

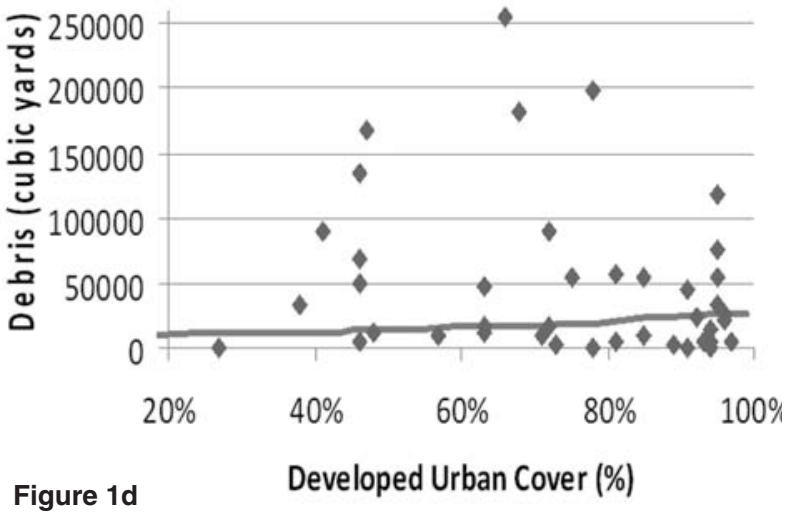

Figure 1d

Figure 1. Predicted debris (cubic yards) versus (a) tree density (trees/hectare), (b) tree canopy cover (\%), (c) sustained wind speed (kt), and (d) developed urban cover (\%). Diamonds $=$ raw data; solid line $=$ predicted at constant average of all other predictor variables. 
$26 \mathrm{kt})$ to $115 \mathrm{~km} / \mathrm{h}(72 \mathrm{mph} ; 63 \mathrm{kt})$. Monitors measuring winds greater than $121 \mathrm{~km} / \mathrm{h}(75 \mathrm{mph} ; 65.2 \mathrm{kt})$ might have been rendered inoperative by hurricane force winds. Additionally hurricane dynamics are complex and tornadoes, wind bursts or antecedent rain might have more of an influence on debris production than does maximum sustained wind speed (Everham and Brokaw 1996). Also, as hurricanes move inland, wind speeds are reduced but are still capable of causing substantial levels of damage to trees and infrastructure. A substantial increase in tree damage from branch failures has been reported by Luley et al. (2002) to begin around $81 \mathrm{~km} / \mathrm{h}(50 \mathrm{mph} ; 43.4 \mathrm{kt})$. Francis and Gillespie (1991) report tree damage to begin around $60 \mathrm{~km} / \mathrm{h}(37 \mathrm{mph}$; $33 \mathrm{kt}$ ) with damage increasing rapidly to approximately 130 $\mathrm{km} / \mathrm{h}(81 \mathrm{mph} ; 70 \mathrm{kt})$, but not worsening at higher gust speeds.

Results of urban forest damage as expressed by debris generation from this study are consistent with other studies, which found that tree and stand characteristics were the best predictors of damage while storm meteorology was of secondary importance (Kupfer et al. 2008; Oswalt and Oswalt 2008). The relationship between wind speed and debris generation was found to be significantly related, while there are clearly other factors, in addition to wind speed, that are important in debris generation. Assuming that all other effects are at their average over the range of the independent variables, this study indicates that tree canopy cover and density, wind speed, and percent of urban development had complex relationships with debris generation (Figure 1a, Figure 1b).

Increased tree density in a community and high tree canopy cover with increasing winds were two interactions that resulted in decreased debris generation (Figure 1a, Figure 2a). This can possibly be a result of urban forest structure, management, and the effects of past hurricanes. Everham and Brokaw (1996) indicate that uniform canopy heights of wind-impacted forests are less susceptible to windstorms. Because of this, tree canopies collectively reduce turbulences and shed winds. Additionally, the authors report that past and current management activities might selectively remove susceptible trees and change species and size composition to a more wind-resistant structure.

This study's results also suggest that models and methods that use tree cover or wind speed alone might not be considering important factors that influence tree debris generation (FEMA, 2007a). However, other factors such as urban forest structure and impact of prior hurricane events warrant further investigation and could improve the reliability of multivariate models (Everham and Brokaw 1996; Kupfer et al. 2008).

This study found that debris generation varied from a low average of $0.59 \mathrm{~m}^{3}\left(0.77 \mathrm{yd}^{3}\right)$, per $30.5 \mathrm{~m}$ of street segment for low damage, $3.4 \mathrm{~m}^{3}\left(4.44 \mathrm{yd}^{3}\right)$ for moderate damage, and $17.47 \mathrm{~m}^{3}\left(22.85 \mathrm{yd}^{3}\right)$ for high damage levels. Given the variability of cubic meter debris production in the sampled communities, these damage level averages are plausible and within range of past post-storm tree debris production events (Rankin 2000). These averages can be applied by a Florida community, who can use street lengths to obtain a preliminary estimate of potential debris generation from their urban forest.

It is interesting to note that tree removal rates were surprisingly low in the communities that reported these data. One reason may be that trees needing removal were treated as debris and removed during debris removal activities. Alternatively, it is possible that standing trees were not removed regardless of the

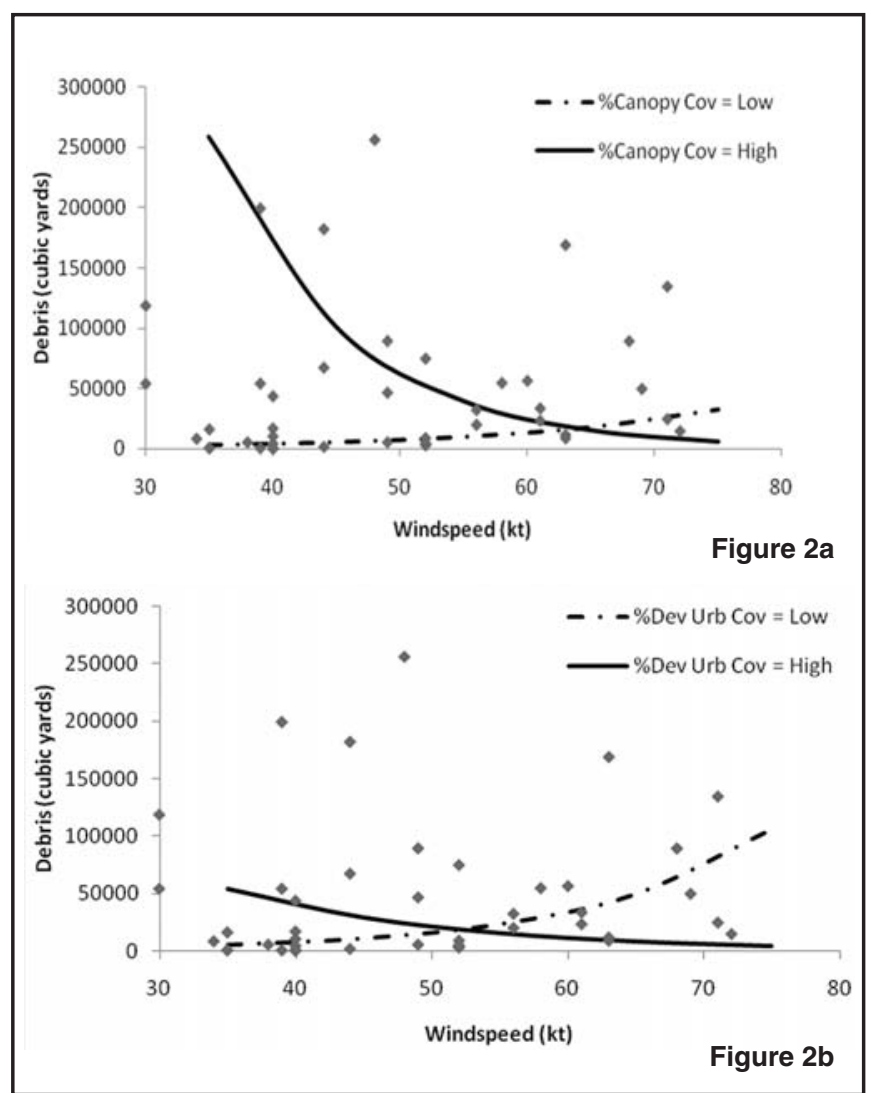

Figure 2. Graphs depicting two-way wind speed interaction of debris generation using low and high values of (a) percent tree canopy cover (\%Canopy Cov) and (b) percent developed urban cover (\%Dev Urb Cov). Low and high values used were $10 \%$ and $30 \%$ tree canopy and $50 \%$ and $90 \%$ developed urban cover, respectively.

level of damage. Tree pruning rates were more consistent with ice storm events in the northeast United States (Bloniarz et al. 2001).

An important difference between ice storm damage cleanup in the northeast US and hurricane storm damage clean up in our sample is the use of unit costing for tree removals and pruning, or the inclusion of tree removal and pruning costs in debris cleanup costs. This is suggested by the absence of reported tree removal and pruning data in PWs, the absence of itemized (e.g., diameter class) data for these costs when calling communities, and the common use of a unit costing approach in PWs. We concluded from our limited data that itemization of costs for tree pruning and removal is rare for hurricanes in Florida, despite FEMA's requesting this approach in their formal documentation (FEMA, 2007a).

Limitations of this study included the few data that were reported in PWs or available from communities are related to the direct exploration of any relationships between specific costs, tree removal and hazard pruning rates, and wind speed. In fact, we only obtained usable pruning and removal data from two communities, which had data by tree as required by FEMA. Since communities apparently use unit costing or report removal and pruning costs with debris clean up, these data will be more difficult to obtain than debris removal estimates. Additionally, recent and state-wide Florida urban forest cover and structure data are unavailable. Clearly, it would be desirable to find additional data such as these so that more robust numbers may be used for vegetation debris estimates. 
Urban forests in Florida are prone to hurricanes, and as a result, a substantial portion of post-hurricane debris is from trees. Hurricane and tree debris must be considered in urban forest management plans and emergency management activities (Escobedo et al. 2007). Thus, there is a need to support local and regional governments with timely information on the extent and location of damage to urban forests, as well as tools to help plan for and manage the debris generated, resources for clean up, and eventual restoration of urban forest structure and function. This study found significant differences in Florida hurricane debris and its management from what the literature suggests. These results need to be communicated to concerned officials and researchers to improve our confidence in the estimation of hurricane damage to urban forests and the associated costs.

Acknowledgements. This study was funded by the Florida DACS-Division of Forestry. We thank Andrew Kittsley, David Metzker, Cecilia Meeks, Steve Simpson, Wayne Zipperer, David Nowak, and Eric Greenfield for providing data as well as Benjamin Thompson, Eric Kuehler, Dudley Hartel, Charlie Marcus and two anonymous reviewers for helpful comments on earlier drafts of this manuscript.

\section{LITERATURE CITED}

Bloniarz, D. V., D.P. Ryan, C.J. Luley, J. Bond, and D.C. Hawkins. 2001. An Initial Storm Damage Assessment Protocol for Urban and Community Forests. 15 June 2008. <http://www.urbanforestrysouth.org/ resources/library/TTResource.2004-12-02.0911/file>.

COES. 2005. Disaster Debris Management Training Manual. State of California, Governor's Office of Emergency Services. Response and Recovery Division, Technical Assistance Programs. Mather CA. 188 pp.

Duryea, M.L. 1997. Wind and Trees: Surveys of Tree Damage in the Florida Panhandle after Hurricanes Erin and Opal. Circular 1183, Florida Cooperative Extension Service, Institute of Food and Agricultural Sciences, University of Florida.

Duryea, M.L., E. Kampf, and R.C. Littell. 2007a. Hurricanes and the Urban Forest: I. Effects on Southeastern U.S. Coastal Plain Tree Species. Arboriculture and Urban Forestry 33(2): 83-97.

Duryea, M.L., E. Kampf, R.C. Littell, and C.D. Rodríguez-Pedraza. 2007b. Hurricanes and the Urban Forest: II. Effects on Tropical and Subtropical Tree Species. Arboriculture and Urban Forestry 33(2): 98-112.

Escambia County. 2004. Hurricane Ivan Strom Debris Removal. Escambia County Board of County Commissioners Meeting-October 22, 2004. 15 June 2008..<http://www.co.escambia.fl.us/documents/Hurricane_Ivan_Status_Report_10-22-04.pdf>.

Escobedo, F., Northrop, R. and Zipperer, W. 2007. Developing an urban forest management plan for hurricane-prone communities. University of Florida- IFAS, EDIS FOR 121/FR176. 16 June 2008. <http://edis. ifas.ufl.edu/pdffiles/FR/FR17600.pdf>.

Escobedo, F., S. Varela, B. Thompson, and C. Staudhammer. 2008. Pensacola Florida's urban forest. University of Florida- IFAS, EDIS publication. In Review.

Everham, E.M. and N.V.L. Brokaw. 1996. Forest damage and recovery from catastrophic wind. Botanical Review 62:113-85.

FEMA. 2004. FEMA-1545-DR, Florida Disaster Declaration as of 12/03/2004. 12 June 2008. <http://www.gismaps.fema. gov/2004graphics/dr1545/dec_1545.pdf>.
FEMA. 2006a. \$1 Billion In Public Assistance For Hurricane Wilma Recovery. FEMA. News Release Number LTR-06-036. 14 June 2008. $<$ http://www.fema.gov/news/newsrelease.fema?id=28220>.

FEMA. 2006b. HAZUS MH MR3 Hurricane Model Technical Manual. 14 June 2008. <http://www.fema.gov/library/viewRecord.do?id=3034>.

FEMA. 2007a. Debris Management Guide. FEMA Publication 325. 06 June 2008. <http://www.fema.gov/government/grant/pa/demagde.shtm>.

FEMA. 2007b. Robert T. Stafford Disaster Relief and Emergency Assistance Act (Public Law 93-288) as amended. FEMA Publication 592. 15 June 2008 . <http://www.fema.gov/pdf/about/stafford_act.pdf>

FEMA. 2007c. Public Assistance and Project Worksheets: The Path to Rebuilding. FEMA News Release Number 1603-656. 15 June 2008. $<$ http://www.fema.gov/news/newsrelease.fema?id=37669>.

Francis, J.K. and A.J.R. Gillespie. 1993. Relating gust speed to tree damage in Hurricane Hugo, 1989. Journal of Arboriculture 19:368-373.

Google Earth. 2007. Google Earth Version 4.2.0198.2451 (beta). 01 June 2008. <http://earth.google.com>.

Gresham, C.A., T.M. William, and D.J. Lipscombe. 1991. Hurricane Hugo wind damage to southeastern U.S. coastal forest tree species. Biotropica 23:420-426.

i-Tree. 2008. i-Tree Software Suite v2.0 User's Manual. 16 June 2008. $<$ http://www.itreetools.org/resource_learning_center/elements/iTree_v20_UsersManual.pdf>.

Kupfer, J.A, A.T. Myers, S.E. McLane, and G.N. Melton. 2008. Patterns of forest damage in a southern Mississippi landscape caused by Hurricane Katrina. Ecosystems 11: 45-60.

Luley, C.J., S. Sisinni, and A. Pleninger. 2002. The effect of wind gust on branch failures. Tree Structure and Mechanics Conference Proceedings. How Trees Stand Up and Fall Down. E.T. Smiley and K.D. Coder, Eds. ISA, Champaign, IL., pp. 103-109.

Mayer, H., T. Trump, and F. Escobedo. 2007. Tree damage and restoration following Hurricanes Katrina and Wilma at Miami Metrozoo. Florida State Horticulture Society Proceedings, 120:320-322.

NOAA. 2004. Tropical Cyclone Report. Hurricane Charley, 9-14 August 2004. 05 June 2008. <http://www.nhc.noaa.gov/pdf/TCRAL032004_Charley.pdf $>$.

Nowak, D.J., E.J. Greenfield, and J.T. Walton. 2008. State Urban and Community Forests. USDA Forest Service Northern Research Station. General Technical Report. In Review.

Oswalt S.N. and C.M. Oswalt. 2008. Relationships between common forest metrics and realized impacts of hurricane Katrina on forest resources in Mississippi. Forest Ecology and Management, 255: 1692-1700.

Rankin, Tom. 2000. Personal communication with DRC, Inc.

SAS. 2006. SAS Institute. The Glimmix Procedure: SAS Publishing; 2006.

Umpierre, D. and G. Margoles. 2005. Broward County's Web-Based Hurricane Debris Estimation Tool (HurDET). Broward County Emergency Management Agency. 16 June 2008. <http://gis.esri.com/ library/userconf/proc05/papers/pap2200.pdf>.

U. S. Census Bureau. 2004. Census 2000 TIGER/Line $®$ Files. 16 June 2008. <http://www.census.gov/geo/www/tiger/tiger2k/tgr2000.html>.

Ward, H. 2002. FEMA Disaster Debris Planning. RCRA National Meeting Presentation. 10 June 2008. <http://www.epa.gov/epaoswer/osw/ meeting/pdf02/ward.pdf>. 
Francisco J. Escobedo (corresponding author)

University of Florida- IFAS

School of Forest Resources and Conservation

P.O. Box 110806

Gainesville, Florida 32611, U.S.

fescobed@ufl.edu

Christopher J. Luley

Urban Forestry LLC

6050 Hicks Rd.

Naples, NY 14512, U.S.

Jerry Bond

Urban Forestry LLC

3904 Willowdale Lane

Geneva, NY 14456, U.S.

Christina Staudhammer

University of Florida-IFAS

School of Forest Resources and Conservation

P.O. Box 110410

Gainesville, Florida 32611, U.S.

Charles Bartel

Florida Division of Emergency Management

2555 Shumard Oak Boulevard

Tallahassee, FL 32399, U.S.

Résumé. Un échantillon aléatoire de $10 \%$ de municipalités de Floride ayant subi de lourds impacts par les ouragans de 2004 et 2005 a été utilisé pour étudier la production de débris d'arbres et les dommages provenant de sept ouragans. Les débris ligneux ont été mesurés en fonction du nombre de mètres cubes tout comme en fonction de la valeur et du coût de nettoyage, d'abattage et d'élagage d'arbres pour ces événements. La production moyenne de débris s'élevait, pour chaque tronçon de rue de $30,5 \mathrm{~m}$ de longueur, à $0,59 \mathrm{~m}^{3}$ lors de faible dommages, à $3,4 \mathrm{~m}^{3}$ lors de dommages modérés et à $17,47 \mathrm{~m}^{3}$ lors de dommages élevés; les coûts de ramassage et de disposition étaient en moyenne de $28,25 \$ / \mathrm{m}^{3}$. La plupart des municipalités utilisaient des coûts unitaires pour quantifier les taux d'abattage et d'élagage, qui étaient de respectivement $2 \%$ et $28 \%$ pour les arbres de rues. La couverture en arbres, la vitesse des vents et le pourcentage de développement urbain du territoire ont tous eu un effet significatif sur la quantité de débris. Les municipalités de Floride avec une plus grande densité en arbres ont produit des quantités décroissantes de débris durant la saison des ouragans de 2004 et 2005. Ces résultats peuvent aider les municipalités à planifier des activités de gestion des ouragans et à estimer le potentiel de dommages au sein de la ressource arbre.

Zusammenfassung. Eine zufällige 10 \%ige Probe aus Gemeinden mit schweren Sturmschäden in der Saison 2004 und 2005 in Florida wurde verwendet, um die Reste und den Schaden von sieben schweren Stürmen zu untersuchen. Die Mengen an gefallenen Bäumen (in $\mathrm{m}^{3}$ ), sowie die Kosten für die Bruchholzbeseitigung, Baumfällung und Baumschnitt aus diesen Ereignissen wurden erhoben. Die durchschnittliche Bruchholzmenge pro 30,5 m Straßensegment betrug $0,59 \mathrm{~m}^{3}$ für geringen Schaden, 3,4 $\mathrm{m}^{3}$ für mittleren Schaden und 17,47 $\mathrm{m}^{3}$ für hohe Schadensgrade, die durchschnittlichen Kosten für die Beseitigung betrugen $\$ 28,25 / \mathrm{m}^{3}$. Die meisten Kommunen benutzten Einheitskosten für Baumfällung und -pflege, durchschnittlich 2 bis $28 \%$ der Straßenbäume. Die Baumkrone, Windgeschwindigkeit und Anteil der bebauten Fläche, alles hatte einen deutlichen Anteil an dem Bruchholzaufkommen. Die Gemeinden in Florida mit größerem Baumvorkommen produzierten 2004 und 2005 einen geringeren Anteil an Bruchholz. Diese Ergebnisse können den Kommunen bei der Planung von Pflegemaßnahmen nach Sturmereignissen helfen und den zu erwartenden Schaden besser einschätzen.

Resumen. Fue empleada una muestra aleatoria del 10\% de comunidades en condados altamente impactados por la temporada de huracanes de Florida de 2004 y 2005 para estudiar la generación de escombros de los árboles y el daño de siete huracanes. Las cantidades de escombros maderables en metros cúbicos (m3) (yardas cúbicas; yd3), como también las tasas y los costos por limpieza, remoción de árboles y poda fueron obtenidas para estos eventos. El promedio de escombros generados por $30.5 \mathrm{~m}$ (100 pies) de segmentos de calles alcanzaron de $0.59 \mathrm{~m} 3$ (0.77 yd3) para bajo daño, $3.4 \mathrm{~m} 3$ (4.44 yd3) para daño moderado, y $17.47 \mathrm{~m} 3$ (22.85 yd3) para altos niveles de daño; el costo de remoción y disposición promedió \$28.25 por m3 (\$21.47 por yd3). La mayoría de las comunidades usaron unidades de costo para contabilizar por remoción de árboles y tasas de poda, promediando $2 \%$ y $28 \%$ de árboles urbanos, respectivamente. La copa del árbol, la velocidad del viento y el porcentaje de terreno urbano desarrollado tuvieron un efecto significativo en la cantidad de escombros. Las comunidades de Florida con mayores densidades de arbolado generaron cantidades reducidas de escombros durante la estación de huracanes de 2004 y 2005. Estos resultados pueden ser usados para ayudar a las comunidades a planear las actividades de manejo de huracanes y la estimación de daños potenciales a sus recursos arbóreos. 